Journal of Agricultural Sciences
(Tarim Bilimleri Dergisi)

\title{
Investigation of The Roles of Hydrogen Peroxide and NADPH Oxidase in The Regulation of Polyamine Metabolism in Maize Plants under Drought Stress Conditions
}

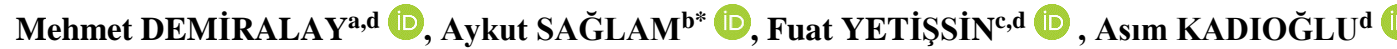 \\ ${ }^{a}$ Department of Forest Engineering, Faculty of Forestry, Artvin Çoruh University, Artvin, 08100, TURKEY \\ ${ }^{b}$ Department of Molecular Biology and Genetics, Faculty of Sciences, Karadeniz Technical University, Trabzon, 61080, TURKEY \\ ${ }^{c}$ Department of Food Processing, Vocational High School of Technical Sciences, Mus Alparslan University, Mus, 49100, TURKEY \\ ${ }^{d}$ Department of Biology, Faculty of Sciences, Karadeniz Technical University, Trabzon, 61080, TURKEY
}

ARTICLE INFO

Research Article

Corresponding Author: Aykut SAĞLAM, E-mail: saglama@ktu.edu.tr

Received: 14 January 2020 / Revised: 08 November 2021 / Accepted: 08 November 2021 / Online: 15 October 2022

Cite this article

DEMIRLIAY M, SAĞLAM A, YETIŞSIN F, KADIOĞLU A (2022). Investigation of The Roles of Hydrogen Peroxide and NADPH Oxidase in The Regulation of Polyamine Metabolism in Maize Plants under Drought Stress Conditions. Journal of Agricultural Sciences (Tarim Bilimleri Dergisi), 28(4):613-625. DOI: 10.15832/ankutbd.861008

\section{ABSTRACT}

The relationship between hydrogen peroxide and the metabolism of polyamines and the role of NADPH oxidase (NOX) in that relationship under drought conditions remains unclear. To reveal the relationship, expression levels of the genes in polyamine metabolism, such as arginine decarboxylase, agmatine aminohydrolase, spermidine synthase, Sadenosyl methionine decarboxylase, diamine oxidase, and polyamine oxidase were determined by RT PCR under drought stress combined with exogenous hydrogen peroxide $\left(\mathrm{H}_{2} \mathrm{O}_{2}\right)$ and diphenyleneiodonium chloride (DPI) treatments in maize seedlings. In addition, some basic stress parameters (leaf water potential, lipid peroxidation), levels of polyamines (putrescine, spermidine, and spermine), and gene expression of NOX were measured under drought stress. Exogenous $\mathrm{H}_{2} \mathrm{O}_{2}$ induced the polyamine content by up-regulating polyamine-synthesizing genes and downregulating polyamine oxidizing genes. When the NOX enzyme was inhibited by DPI, the polyamine pathway tended towards degradation instead of production. Exogenous $\mathrm{H}_{2} \mathrm{O}_{2}$ regulated the metabolism of polyamines to promote their synthesis, and NOX played a key role in that regulation.

Keywords: Antioxidant enzymes, Arginine decarboxylase, Diphenyleneiodonium chloride, Polyamine oxidation, Reactive oxygen species

\section{Introduction}

Polyamines, similar to hormones, have been considered to function as regulatory molecules in several basic cellular and physiological processes such as cell division, differentiation, and proliferation, cell death, membrane stabilization, DNA replication, protein synthesis, flower formation and development, leaf senescence, fruit development and maturation, biotic and abiotic stress responses (Alcazar et al. 2006a; Kusano et al. 2008). Recent studies of transgenic and mutant plants with excess or less polyamine suggest that polyamines play a protective role against abiotic stress (Alcazar et al. 2006b; Kusano et al. 2008; Gill \& Tuteja 2010). For instance, the excessive level of putrescine in the Arabidopsis plant by overexpression of the Arginine decarboxylase $2(A D C 2)$ gene has probably stimulated stomal closure, and this decrease in water loss increased drought tolerance (Alcazar et al. 2010a). In a study by Kusano et al. (2007), Arabidopsis acl5/spms double mutant plants, which are unable to produce spermine, became hypersensitive to drought and saline stress. In the same study, however, the externally applied spermine mitigated the effects of the stresses mentioned in the plant. Besides, Yamaguchi et al. (2006; 2007) reported that the susceptibility to drought and salt stresses increased in the studies with double mutants of spms1/acl5-1 of Arabidopsis to investigate the protective role of spermine against abiotic stress.

Drought stress is known to increase the generation of reactive oxygen species (ROS) in cell compartments such as chloroplasts, peroxisomes, and mitochondria. Be exposed to environmental stresses, such as drought, chilling, heat, or high light irradiation, is considered to lead to high concentrations of ROS, such as superoxide, $\mathrm{H}_{2} \mathrm{O}_{2}$, single oxygen, and hydroxyl radical (Das \& Roychoudhury 2014; Akyol et al. 2020). If drought stress is prolonged, ROS production becomes dominant over the scavenging capacity of the antioxidant system, resulting in extensive cellular damage and death (Cruz de Carvalho 2008). On the other hand, ROS function as signal molecules in plants (Waszczak et al. 2018), controlling growth, development, responses to biotic and abiotic environmental stimuli, and programmed cell death (Bailey-Serres \& Mittler 2006). The production of $\mathrm{H}_{2} \mathrm{O}_{2}$ is strongly associated with the catabolic processes of polyamine. Because $\mathrm{H}_{2} \mathrm{O}_{2}$ is not only produced by the of NADPH oxidases 
(NOX), but also by amine oxidases (Cona et al. 2006a; 2006b). Apoplastic polyamine oxidase in tobacco and polyamine oxidase encoded by the Arabidopsis polyamine oxidase 3 (AtPAO3) gene have been documented to contribute to the production of $\mathrm{H}_{2} \mathrm{O}_{2}$ (Moschou et al. 2008a; Wu et al. 2010). Polyamine oxidation has been reported to be regulated by polyamine oxidases at different levels of expression in Arabidopsis thaliana, thus rendering ROS levels is quite complex (Fincato et al. 2011). Many studies confirm that NOX homologs are essential for ROS accumulation in plants (Kwak et al. 2003; Sagi et al. 2004; Torres et al. 2005). Mutants of the NADPH oxidase genes have been employed in most of these studies. ROS accumulation, especially $\mathrm{H}_{2} \mathrm{O}_{2}$, decreases in these plants. Papadakis \& Roubelakis-Angelakis (2005) have suggested that the cross-linking between polyamines and NOX regulates protoplast regeneration in a tobacco plant. Andronis et al. (2014) have found that exogenously applied polyamines stimulate NADPH oxidase-dependent oxygen consumption in Arabidopsis. In the study, the amount of oxygen in the mutant plants carrying the overexpressed AtPAO3 gene decreased compared to the mutant Atpao3 mutant plants with incomplete function. In the Atpao3 mutants, the amount of $\mathrm{H}_{2} \mathrm{O}_{2}$ was low. In the case of AtPAO3 over-expression, the opposite was the case. Andronis et al. (2014) stated that there could be a very strong relationship between polyamines and $\mathrm{H}_{2} \mathrm{O}_{2}$, and this relationship could also be associated with NOX. Furthermore, Liu et al. (2019) determined that exogenously applied putrescin contributed to the development of resistance against pathogenic bacteria in Arabidopsis thaliana. The resistance was found to be dependent on hydrogen peroxide and NOX (RbohD and RbohF). In addition, Seo et al. (2019) found out that NtRbohD and $N t R b o h F$ genes were downregulated in SAMDC overexpressing Nicotiana tabacum under salt stress conditions. Consequently, they concluded that polyamines inhibited the production of ROS. However, the relationship between NADPH oxidase and polyamines has not been fully elucidated under drought stress conditions yet. In the current study, the hypothesis that NOX acts as a regulator in the metabolism of polyamines under drought stress conditions has been tested. For this purpose, the biosynthesis pathway of polyamines in drought-stressed maize plants was studied in detail after the application of $\mathrm{H}_{2} \mathrm{O}_{2}$ and a $\mathrm{NOX}_{\text {inhibitor. }}$

\section{Material and Methods}

\subsection{Plant material and treatments}

Maize seeds (Zea mays L cv Akpinar sensitive to drought, (Guven 2013) provided from Karadeniz Agricultural Research Institute, Samsun, Turkey, were sterilized with $0.1 \% \mathrm{HgCl}_{2}$ for $3 \mathrm{~min}$ and washed with sterilized distilled water (Terzi et al. 2014). Ten seeds were grown in pots containing peat and sand (5:1) in a growth chamber, which was set to $16 \mathrm{~h}$ light (PPFD on the leaf surface per $\left.400 \mu \mathrm{mol} \cdot \mathrm{m}^{-2} \cdot \mathrm{s}^{-1}\right), 8 \mathrm{~h}$ dark photoperiod at $25{ }^{\circ} \mathrm{C} \pm 2$ and ambiance humidity $60 \% \pm 5$. Four-week-old seedlings were cut from near bottom then immersed distilled water for alleviating injury stress, and subsequently, plants were

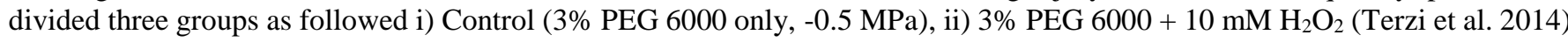
and iii) 3\% PEG $6000+100 \mu \mathrm{M}$ DPI (NOX inhibitor diphenyleneiodonium chloride, Potocký et al. 2007). All treatments were done on the excised seedlings immersed in the test solutions mentioned. The seedlings were kept in the test solutions for 6 hours. At the end of this period, the third leaves from the base of the seedlings were selected and used in the experiments.

\subsection{Leaf water potential}

Leaf water potential (MPa) was measured by using a C52 thermocouple psychrometer (Wescor Inc.). Leaf disks approximately $6 \mathrm{~mm}$ in diameter were placed in the C52 sampling chamber and monitored for one hour with the PSYPRO data logger (Saglam et al. 2011).

\subsection{Lipid peroxidation}

The quantity of thiobarbituric acid reactive substances (TBARS) was measured to determine lipid peroxidation according to Heath \& Packer (1968). Leaf samples (0.25 g) were homogenized with $20 \%$ trichloroacetic acid (TCA) including 5\% thiobarbituric acid (TBA) and centrifuged at $10000 \mathrm{~g}$ for 10 minutes at $4{ }^{\circ} \mathrm{C}$. TBARS content was expressed as nmol $\mathrm{g}^{-1} \mathrm{dry}$ weight.

\subsection{Endogenous $\mathrm{H}_{2} \mathrm{O}_{2}$ content}

The endogenous content of $\mathrm{H}_{2} \mathrm{O}_{2}$ was measured according to Velikova et al. (2000). Frozen leaf samples (0.25 g) were homogenized with $1 \%$ TCA and centrifuged at $15000 \mathrm{~g}$ for 15 minutes at $4{ }^{\circ} \mathrm{C}$. The resultant supernatant was added to the reaction mixture, including $10 \mathrm{Mm}$ of potassium phosphate buffer ( $\mathrm{pH} 7)$, and $1 \mathrm{M}$ of potassium iodide (KI). Absorbance was measured at $390 \mathrm{~nm}$. The $\mathrm{H}_{2} \mathrm{O}_{2}$ content was given as nmol g-1 dry weight.

\subsection{Enzyme activities}

Leaf samples $(0.1 \mathrm{~g})$ were pulverized in liquid nitrogen and extracted with $1.8 \mathrm{ml}$ of extraction buffer $\left(100 \mathrm{mM} \mathrm{K}_{2} \mathrm{HPO}_{4}, 0.1\right.$ mM EDTA $\mathrm{pH} 7.0,0.1 \%$ Triton). The extracts were centrifuged at $15000 \mathrm{~g}$ for 20 minutes at $4{ }^{\circ} \mathrm{C}$. The resultant supernatant was used to determine enzyme activity. 
The activity of NADPH oxidase (EC 1.6.3.1) was measured by Cakmak \& Marschner (1988). NADPH oxidase activity was determined based on NADPH's oxidation at $340 \mathrm{~nm}\left(\mathcal{E}=6.2 \mathrm{mM} \mathrm{cm}^{-1}\right)$. Enzyme activity was determined based on the decrease in absorbance for 3 minutes in the reaction medium consisting of $100 \mathrm{mM}$ of potassium phosphate buffer (pH 7.0), $0.1 \mathrm{mM}$ of EDTA, and $100 \mu \mathrm{M}$ of NADPH.

Catalase (EC 1.11.1.6) activity was determined according to Aebi (1983). Enzyme activity was determined by measuring a $1 \mathrm{~mL}$ reaction mixture containing $50 \mathrm{mM}$ of potassium phosphate buffer ( $\mathrm{pH} 7.0), 30 \mathrm{mM}$ of $\mathrm{H}_{2} \mathrm{O}_{2}$, and $20 \mu l$ of enzyme extract at $240 \mathrm{~nm}$ for 5 minutes. The catalase activity was calculated by using the extraction coefficient $\varepsilon=39.4 \mathrm{mM} \mathrm{cm}^{-1}$ for $\mathrm{H}_{2} \mathrm{O}_{2}$.

Peroxidase (EC 1.11.1.7) activity was determined according to Urbanek et al. (1991). The enzyme activity was determined by measuring the $2 \mathrm{~mL}$ reaction mixture containing $100 \mathrm{mM}$ of potassium phosphate buffer (pH 7.0), 0.1 mM of EDTA, $5 \mathrm{mM}$ of guaiacol, $15 \mathrm{mM}$ of $\mathrm{H}_{2} \mathrm{O}_{2}$, and $50 \mu \mathrm{l}$ of enzyme extract for 1 minute at $470 \mathrm{~nm}$. The peroxidase activity was calculated using the extinction coefficient $\left(\mathcal{E}=26.6 \mathrm{mM}^{-1} \mathrm{~cm}^{-1}\right)$.

The activity of superoxide dismutase (EC 1.15.1.1) was determined according to Beauchamp \& Fridovich (1971). The reaction was started by adding $2 \mu \mathrm{M}$ of riboflavin to $1 \mathrm{~mL}$ reaction medium containing $50 \mathrm{mM}$ of potassium phosphate buffer (pH 7.8), $0.1 \mathrm{mM}$ of EDTA, $13 \mathrm{mM}$ of methionine, $75 \mu \mathrm{M}$ of nitro blue tetrazolium and $50 \mu \mathrm{l}$ of extract. Following exposure to white light at $375 \mu \mathrm{mol} \mathrm{m} \mathrm{m}^{-2}$, absorption values were determined at $560 \mathrm{~nm}$.

\subsection{Polyamine content}

The determination of polyamines was performed as outlined in Terzi et al. (2014). Briefly, the fresh leaves (5g) were homogenized with $10 \mathrm{~mL}$ of perchloric acid $0.4 \mathrm{M}$. The homogenate was centrifuged at $3000 \mathrm{~g}$ for 4 minutes at $4{ }^{\circ} \mathrm{C}$. The supernatant was collected and perchloric acid $(10 \mathrm{~mL}$ of $0.4 \mathrm{M})$ was added to the supernatant. This mixture was then recentrifuged. $\mathrm{NaOH}(1 \mathrm{M})$ and sodium hydrogen carbonate were added to $1 \mathrm{~mL}$ of the supernatant. The mixture was vortexed for 30 seconds. Subsequently, $2 \mathrm{ml}$ of dansylchloride chloride was added (10 mg ml-1 in acetone). The reaction was stopped with $0.1 \mathrm{~mL}$ of $25 \%$ ammonium hydroxide. An HPLC device with UV/VIS detector (Shimadzu, LC 20 AT / Prominence, Japan) read the polyamine content. The mobile phase consisted of $0.1 \mathrm{M}$ ammonium acetate and $19 \mathrm{M}$ acetonitrile $(65: 35 \mathrm{v} / \mathrm{v})$. The flow rate was $0.70 \mathrm{~mL} \mathrm{~min}^{-1}$ and the column temperature was $50{ }^{\circ} \mathrm{C}$. The $20 \mu 1$ sample was injected into the $\mathrm{C} 18$ column $(4.6 \times 250 \mathrm{~mm}$ Supelco, Bellefonte, USA). Polyamines were determined at $254 \mathrm{~nm}$ wavelength. Peak fields of the polyamines were recorded, then putrescine (put), spermine (spm), and spermidine (spd) concentrations were calculated using LabSolutions software. The concentrations were expressed in $\mu \mathrm{g} \mathrm{g}^{-1}$ dry weight.

\subsection{Protein content}

Protein determination was performed spectrophotometrically according to Bradford (1976). Thirty microliters of sample were used from the extracts prepared for enzymatic activity. Bovine serum albumin (BSA) standards were prepared, and the complex of proteins with Coomassie Brillant Blue G250 was measured at $595 \mathrm{~nm}$. The protein concentration was determined in mg and used for enzyme activities.

\subsection{RNA isolation and cDNA synthesis}

Fresh leaf samples $(0.1 \mathrm{~g})$ were used for total RNA isolation. Total RNA isolation was carried out using a total RNA isolation kit (RNeasy Plant Mini Kit 74904, Qiagen Netherlands). The samples frozen with liquid nitrogen were ground by tissue homogenizer (TissueLyser LT, Qiagen Germany). The amount and the purity of the RNA samples were measured using a nanodrop spectrophotometer (Thermo Scientific, Nanodrop 2000, America). A c-DNA reverse transcription kit (4368814, Applied Biosystems America) was used for the synthesis of c-DNA from the isolated total RNA. The cDNA concentration was adjusted to $2000 \mathrm{ng}$ in each group. The synthesized cDNAs were stored at $-20^{\circ} \mathrm{C}$ until Real-Time PCR analyses were performed.

\subsection{Quantitative Real-Time PCR analysis}

The c-DNAs from the previous step were used in the Real-Time PCR analysis to determine gene expression. 5x HOT FIREPol Eva Green qPCR Supermix (08-36-00008, Solis Biodyne, Estonia) was used to analyze gene expression through CFX Connect Real-Time PCR system (BioRad, USA). RT PCR protocol modified according to Solis Biodyne instructions was as follows 12 minutes at $95{ }^{\circ} \mathrm{C}, 45$ cycles at $95{ }^{\circ} \mathrm{C}, 30$ seconds at $60{ }^{\circ} \mathrm{C}, 30$ seconds at $72{ }^{\circ} \mathrm{C}$. The melt curve was held in $0.5^{\circ} \mathrm{C}$ increments from 60 to $95{ }^{\circ} \mathrm{C}$. The primers were designed with Primer 3 plus (http://primer3plus.com/cgi-bin/dev/primer3plus.cgi). As a reference for gene expression, primers belonging to the Actin1 gene were used. In the study, the genes targeted for expression and primers from those genes were given in Table 1. 
Table 1- The sequences of specific primers used for qRT-PCR analysis

\begin{tabular}{|c|c|c|}
\hline Target gene & NCBI accession no. & Primer names and their sequences \\
\hline \multirow[t]{2}{*}{ Actin 1} & NM_001155179.1 & ACT1Zm_F: "GAAGATCACCCTGTGCTGCT" \\
\hline & & ACT1Zm_R: "ACCAGTTGTTCGCCCACTAG" \\
\hline \multirow[t]{2}{*}{ Arginine decarboxylase (ADC) } & EU968980.1 & ADCZm_F_F: "GACATCACCTGCGACAGTGA" \\
\hline & & ADCZm_R: "GAACAGGTTGTGCTTGCCAG" \\
\hline \multirow{2}{*}{ Spermidine synthase (SPDS) } & EU976300.1 & SPDSZm_F: “TTCCCCTGTTCGATTCACCG” \\
\hline & & SPDSZm_R: "GCAGAACCGTTTCTTGCGTC" \\
\hline \multirow[t]{2}{*}{ Agmatine iminohydrolase (AIH) } & NM_001156428.1 & AIHZm_F: “GACGAGGATACAAACGGCCA" \\
\hline & & AIHZm_R: "ACGGACTGGGAGAGAACAGA" \\
\hline \multirow[t]{2}{*}{ S-Adenosylmethionine decarboxylase (SAMDC) } & EU968400.1 & SAMDCZm_F: “GGAGGCGTGAAGAAGTTCCA" \\
\hline & & SAMDCZm_R: "TTATCAGGAAGCAGCAGGCC" \\
\hline \multirow[t]{2}{*}{ Diamine oxidase (DAO) } & NM_001152492.1 & DAOZm_F: “ACAGCAAGTCCGAGAAGTGG” \\
\hline & & DAOZm_R: "TGTACCACAGCACGATGTCC" \\
\hline \multirow[t]{2}{*}{ Polyamine oxidase 1 (PAO) } & NM_001111636.1 & PAOZm_F: "CGCTACGAATACGACCAGCT" \\
\hline & & PAOZm_R: "TGGGCGCAGTTGATGAGAAT" \\
\hline \multirow[t]{2}{*}{ NADPH oxidase B } & DQ890023.1 & NOXZm_F: "GGGCCAGTACTTCGGTGAAA" \\
\hline & & NOXZm_R: "AAGCTTCACCAGGCTACGAC" \\
\hline
\end{tabular}

\subsection{Statistical analysis}

The variance analysis of means obtained as a result of the analyzes with three replications with 10 samples was performed according to the one-way ANOVA (Duncan Multiple Comparison Test) included in the package of the Statistical Package for Social Sciences (SPSS 16.0 for Windows) at $\mathrm{P}<0.05$. The relative gene expression level was analyzed by the Bio-Rad CFX Manager 3.1. Expression levels were also assayed by SPSS software. Variance analysis of mean values was carried out by oneway ANOVA $(\mathrm{P}<0.05)$.

\section{Results and Discussion}

Water potential measurements were performed to determine the effect of $\mathrm{H}_{2} \mathrm{O}_{2}$ on the water content of maize plants subjected to drought stress conditions. Leaf water potential has been regarded as a good indicator of drought stress (Shaw et al. 2002). Sharma $\&$ Dubey (2005) reported in their study that the water potential of rice plants exposed to drought stress could be reduced from $0.5 \mathrm{MPa}$ to $-2 \mathrm{MPa}$. Similarly, drought stress in wheat reduced leaf water potential from -0.63 MPa to $-2 \mathrm{MPa}$ (Siddique et al. 2000). Unlike the above studies, Terzi et al. (2014) determined that the water potential of the leaf increased in drought stress conditions with the application of $\mathrm{H}_{2} \mathrm{O}_{2}$ in maize plants compared to control (PEG only). Likewise, in the current study, the leaf water status was improved by the $\mathrm{H}_{2} \mathrm{O}_{2}$ application (Figure 1a). The water potential of the $\mathrm{H}_{2} \mathrm{O}_{2}$-treated group was 1.2-fold higher than that of the control group (PEG only), and the levels of polyamine increased along with this improvement. Following the use of DPI to reduce the endogenous $\mathrm{H}_{2} \mathrm{O}_{2}$ content, there was a decrease in the leaf water potential and the polyamine content. The water potential of the DPI group was 1.3-fold lower than that of the control group. The water potential value of the DPI group was also less than that of the $\mathrm{H}_{2} \mathrm{O}_{2}$ group. The water potential of the DPI group was 1.65 -fold lower than that of the $\mathrm{H}_{2} \mathrm{O}_{2}$-treated group. DPI was found to influence the water status of the plant by decreasing the water potential relative to the control group (PEG application). The reduction suggested that applying $\mathrm{H}_{2} \mathrm{O}_{2}$ could affect water potential by regulating polyamine metabolism. As is known, polyamines play a role as an osmotic regulator in drought stress (Sequera-Mutiozabal et al. 2017). 

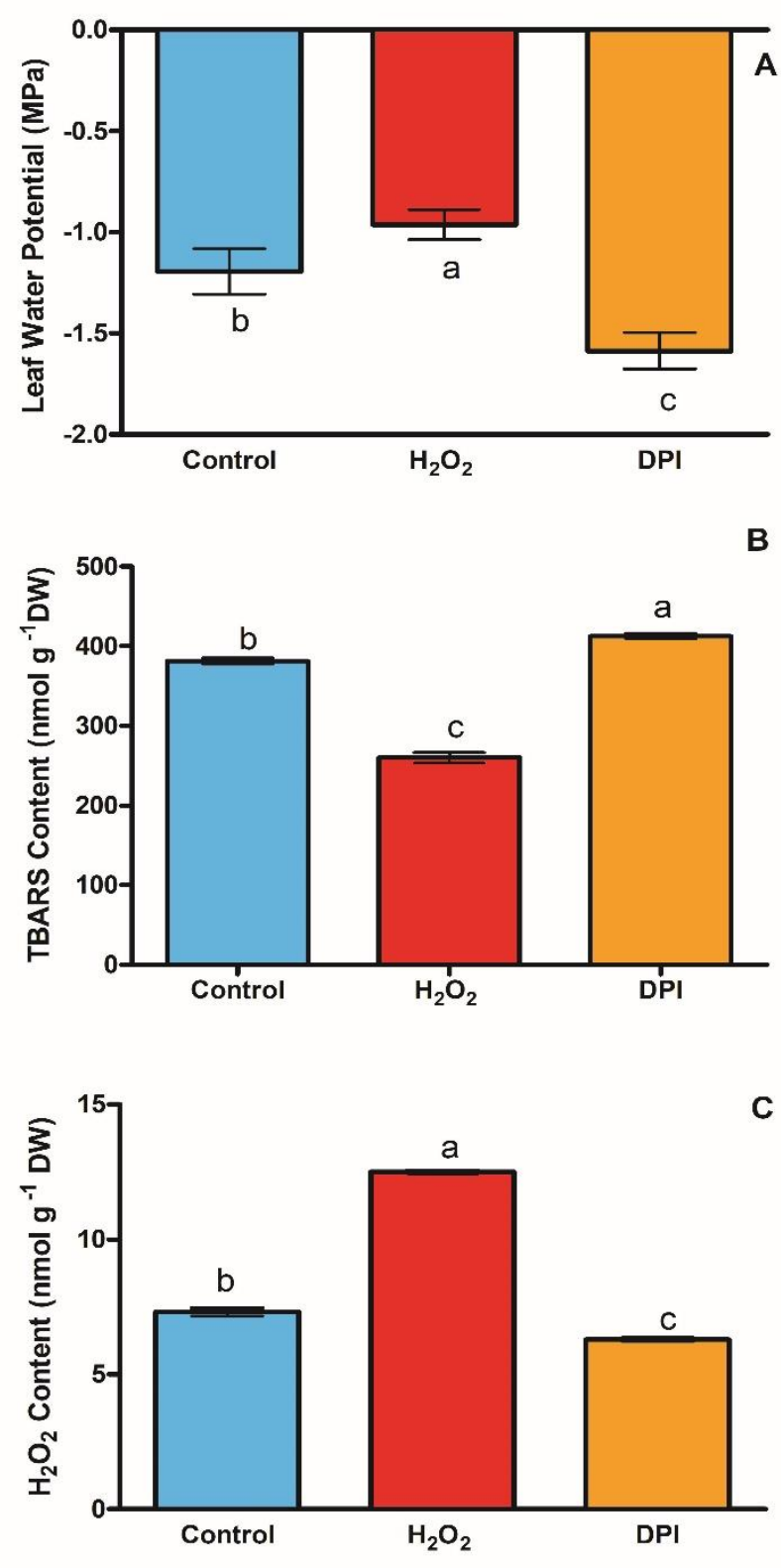

Figure 1- Effect of exogenous $\mathrm{H}_{2} \mathrm{O}_{2}$ and DPI on leaf water potential (A) TBARS (B) and endogenous $\mathrm{H}_{2} \mathrm{O}_{2}$ contents in the leaves of detached maize seedlings under PEG-induced drought stress conditions. The seedlings were submitted to three treatments: Applied with PEG (Control); applied with $\mathrm{H}_{2} \mathrm{O}_{2}$ and PEG $\left(\mathrm{H}_{2} \mathrm{O}_{2}\right)$; applied with DPI and PEG (DPI). Vertical bars are standard deviations. Different letters indicate significant differences among different treatments at $\mathrm{P}<0.05$

In the present study, lipid peroxidation was measured to determine the effects of $\mathrm{H}_{2} \mathrm{O}_{2}$ and DPI on membrane damage under drought stress. ROS is known to cause high levels of lipid peroxidation, resulting in damage to cell membranes (Munne-Bosch et al. 2001). However, in our study, the $10 \mathrm{mM}$ of $\mathrm{H}_{2} \mathrm{O}_{2}$ was determined to reduce lipid peroxidation under drought stress conditions (Figure 1b). The TBARS content of the $\mathrm{H}_{2} \mathrm{O}_{2}$-treated group was 1.5 -fold lower than that of the control group. The amount of TBARS measured in the DPI group was significantly increased concerning the control and the $\mathrm{H}_{2} \mathrm{O}_{2}$-treated groups. The TBARS content of the DPI group was 1.1 and 1.6-fold higher than the control and the $\mathrm{H}_{2} \mathrm{O}_{2}$-treated groups respectively. Furthermore, the application of $10 \mathrm{mM} \mathrm{H}_{2} \mathrm{O}_{2}$ significantly increased the endogenous level of $\mathrm{H}_{2} \mathrm{O}_{2}$ compared with the control group. The endogenous $\mathrm{H}_{2} \mathrm{O}_{2}$ content of the $\mathrm{H}_{2} \mathrm{O}_{2}$-treated group was 1.7-fold higher than that of the control group. Following DPI treatment, the level of endogenous $\mathrm{H}_{2} \mathrm{O}_{2}$ decreased significantly in comparison with the control and $\mathrm{H}_{2} \mathrm{O}_{2}$ groups (Figure 1c). The endogenous $\mathrm{H}_{2} \mathrm{O}_{2}$ content of the DPI group was 1.2 and 2.0 times lower than the control group and the $\mathrm{H}_{2} \mathrm{O}_{2}$ treated group, respectively. Here, $\mathrm{H}_{2} \mathrm{O}_{2}$ applied exogenously may have caused the endogenous hydrogen peroxide to act as a signal molecule and stimulate antioxidants. The stimulation of antioxidants in response to a non-lethal dose of hydrogen peroxide allows cells to adapt to exposure to a much larger dose and thus survive (Rodríguez-Rojas et al. 2020).

Similarly, in our study, the application of $\mathrm{H}_{2} \mathrm{O}_{2}$ increased catalase (CAT) and peroxidase (POD) activities, but the activity of superoxide dismutase (SOD) declined. The catalase activity of the $\mathrm{H}_{2} \mathrm{O}_{2}$-applied group was 1.3 and 1.4-fold higher than that of 
the control and the DPI groups, respectively (Figure 2a). In the DPI group, the CAT activity was found to be lower than that of the control group. The CAT activity of the DPI group was 1.1-fold lower than that of the control group. POD activity was determined as the highest in the $\mathrm{H}_{2} \mathrm{O}_{2}$ group compared to the control and the DPI groups (Figure 2b). The peroxidase activity of the $\mathrm{H}_{2} \mathrm{O}_{2}$ applied group was 1.3 and 1.4-fold higher than the control and the DPI groups, respectively. Furthermore, because of the DPI application, the activity decreased by 1.1 times compared to the control group. In terms of superoxide dismutase, the highest activity was identified in the control group (Figure 2c). The SOD activity of the control group was 1.5 and 1.6 -fold higher than that of the $\mathrm{H}_{2} \mathrm{O}_{2}$ and DPI groups, respectively. There was no difference between the $\mathrm{H}_{2} \mathrm{O}_{2}$ and DPI groups in terms of the SOD activity.

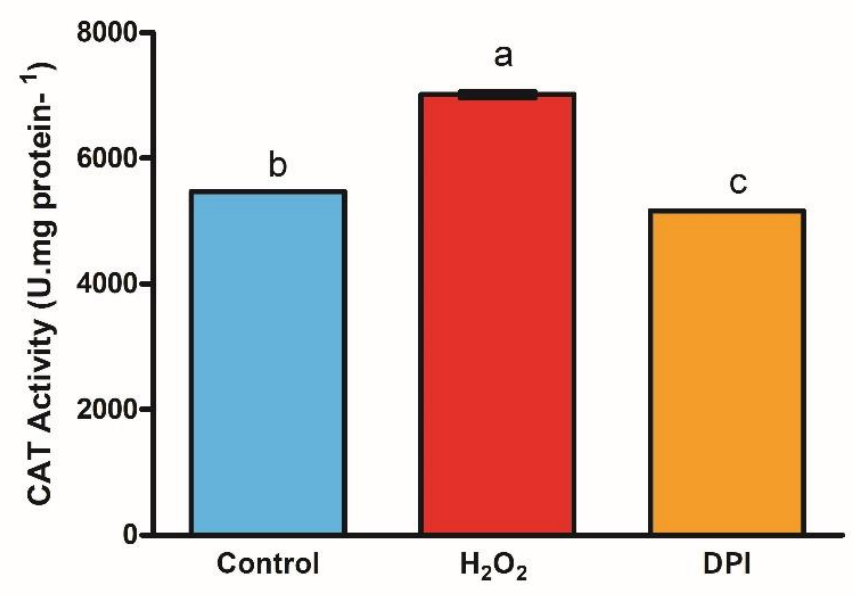

A
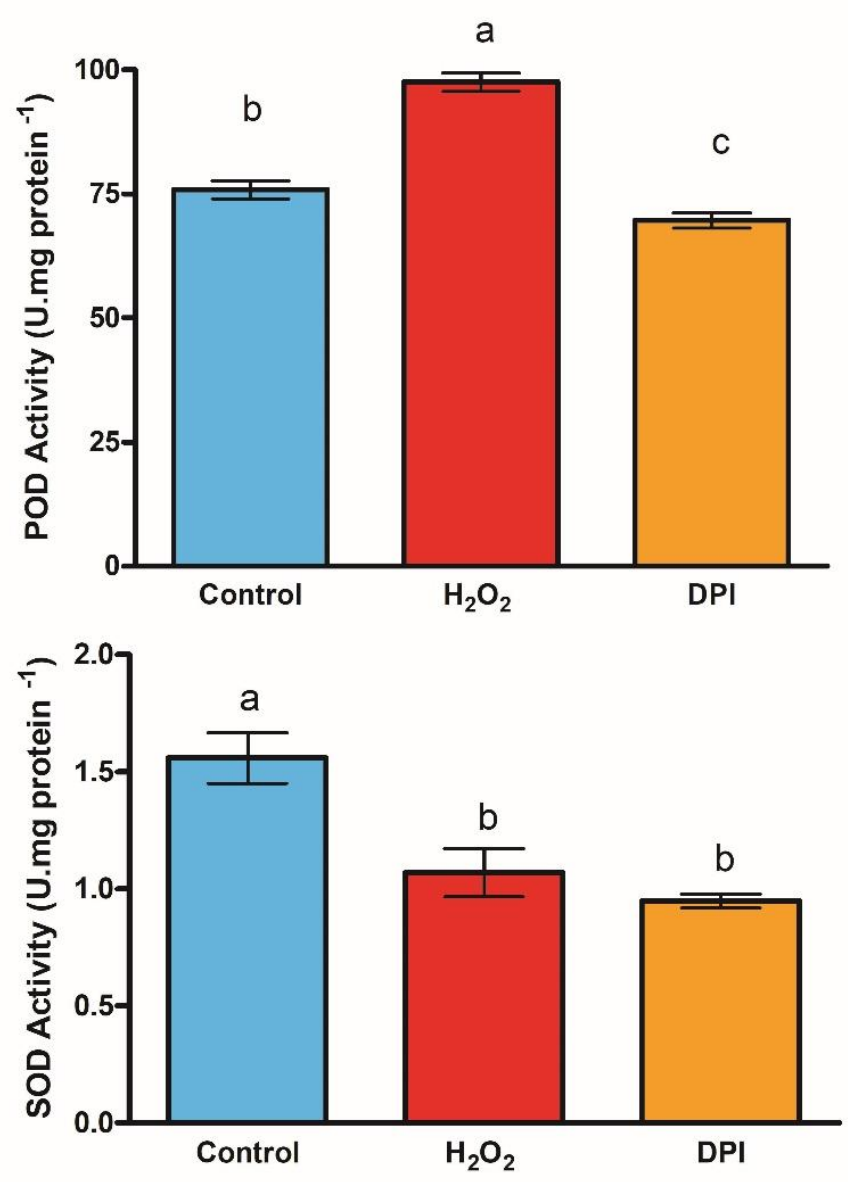

Figure 2- Effect of exogenous $\mathrm{H}_{2} \mathrm{O}_{2}$ and DPI on antioxidant enzyme activities in the leaves of detached maize seedlings under PEG-induced drought stress conditions. Catalase (A), Peroxidase (B) and Superoxide dismutase (C). 
The enzyme catalase is known to scavenge excess $\mathrm{H}_{2} \mathrm{O}_{2}$ by reducing it to water and oxygen (Chaudiere \& Ferrari-Iliou 1999). This enzyme has also been reported to play a role in the prevention of potential damage ( $\operatorname{such}$ as lipid peroxidation) of $\mathrm{H}_{2} \mathrm{O}_{2}$ in membranes (Chaudiere \& Ferrari-Ilioui 1999). Similarly, peroxidases have also been reported to be responsible for scavenging $\mathrm{H}_{2} \mathrm{O}_{2}$ under stress and maintaining cell membrane integrity (Parida \& Das 2005). We concluded that the application of $\mathrm{H}_{2} \mathrm{O}_{2}$ protected the integrity of the cell membrane by inducing catalase and peroxidase activities and therefore reduced TBARS levels. Similar findings were reported in wheat plantings under drought conditions and in cucumber and corn plants under osmotic stress conditions (He et al. 2009; Liu et al. 2010; Terzi et al. 2014). In our study, following the application of DPI, the endogenous $\mathrm{H}_{2} \mathrm{O}_{2}$ level, NADPH oxidase activity, and NOX expression level decreased significantly compared to other groups. The lowest NOX activity was observed in the DPI-treated group (Figure 3a). On the other hand, exogenously applied $\mathrm{H}_{2} \mathrm{O}_{2}$ significantly increased NOX activity compared to the control. The NOX activity of the $\mathrm{H}_{2} \mathrm{O}_{2}$ treated group was 1.1 and 1.3 higher than that of the control and DPI groups, respectively. In addition to NOX activity, the DPI reduced the level of expression of the NOX gene in comparison to the control group (Figure 3b). The NOX expression level of the PDI applied group was 1.3 times lower than that of the control group; however, the highest $N O X$ expression level was found in the $\mathrm{H}_{2} \mathrm{O}_{2}$ group (Figure $3 \mathrm{~b}$ ). The $N O X$ expression of the $\mathrm{H}_{2} \mathrm{O}_{2}$ applied group was 1.4 and 1.9-fold higher than the control and the DPI groups.
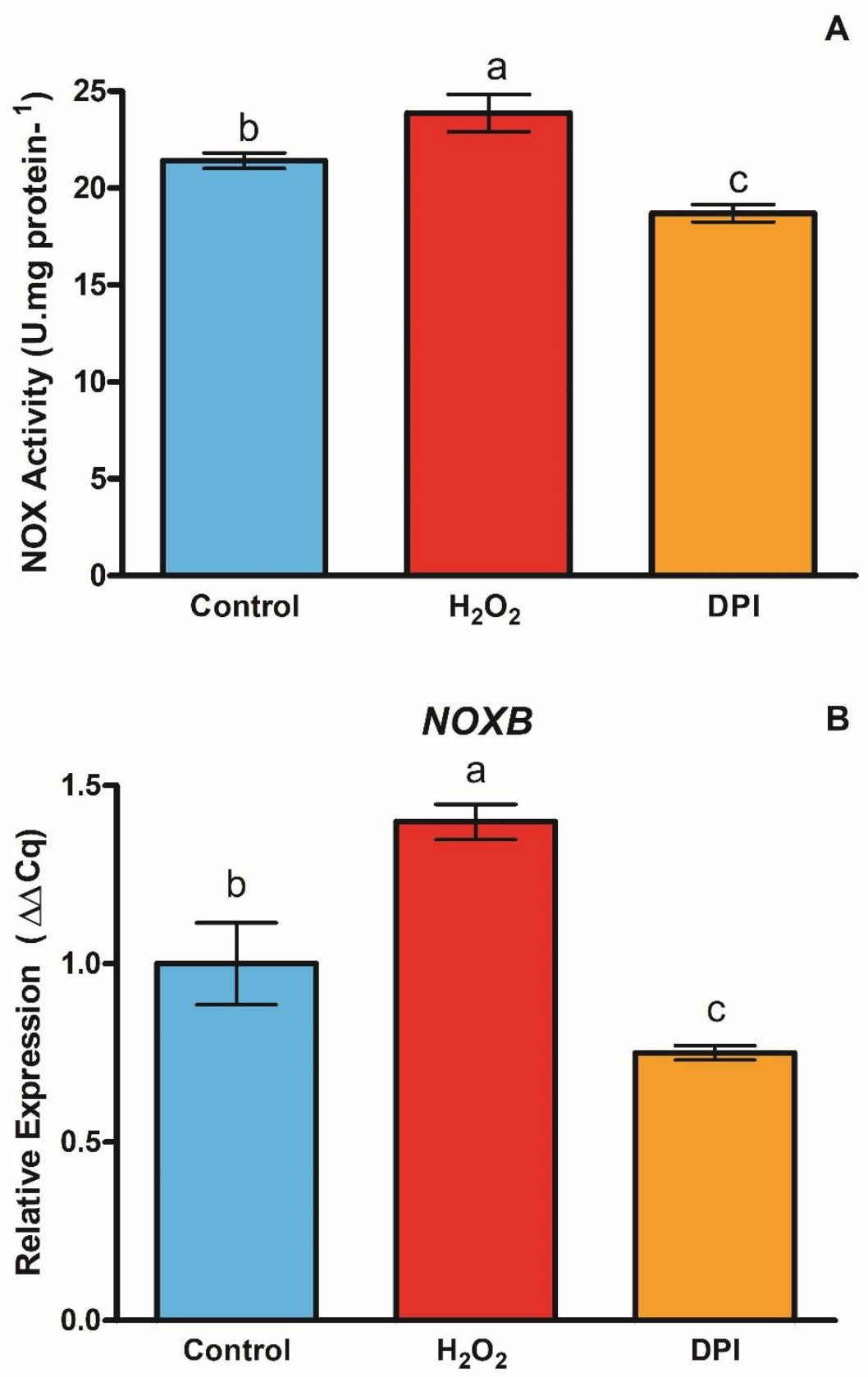

Figure 3- Effect of exogenous $\mathrm{H}_{2} \mathrm{O}_{2}$ and DPI on NADPH oxidase (NOX) activity (A) and NOXB gene expression (B) in the leaves of detached maize seedlings under PEG-induced drought stress conditions. 
The decreases in endogenous $\mathrm{H}_{2} \mathrm{O}_{2}$ level, NADPH oxidase activity, and NOX expression levels and the increased amount of TBARS following the DPI application could be explained by decreasing catalase and peroxidase activities. These changes in enzyme activities showed that hydrogen peroxide acted as a signaling molecule, activated the antioxidant system and protected corn plants from the effects of stress.

Significant increases in levels of endogenous polyamines due to drought stress have been noted in some studies (Erdei et al. 1996; Galston et al. 1997; Groppa \& Benavides 2008). In this study, the application of $\mathrm{H}_{2} \mathrm{O}_{2}$ under drought stress increased the levels of polyamines such as put and spm in comparison with the control group. The maximum put concentration (in all groups) was determined in group $\mathrm{H}_{2} \mathrm{O}_{2}$ (Figure 4). The putrescine level was found to be the lowest in the DPI among all groups. The put content of the $\mathrm{H}_{2} \mathrm{O}_{2}$ treated group was 1.3 and 2.1-fold higher than the control and DPI groups, respectively. The concentration of (spd) in the control group was highest among all groups. The spd content was significantly reduced by the $\mathrm{H}_{2} \mathrm{O}_{2}$ and $\mathrm{DPI}$ treatments relative to the control group. The spd content in the control group was 1.2 and 1.6-fold higher than the $\mathrm{H}_{2} \mathrm{O}_{2}$ and $\mathrm{DPI}$ groups, respectively. Furthermore, the spd content of the $\mathrm{H}_{2} \mathrm{O}_{2}$ group was found to be greater than that of the DPI group. As for the spm content, the application of $\mathrm{H}_{2} \mathrm{O}_{2}$ resulted in the accumulation of spm. The spm content of the $\mathrm{H}_{2} \mathrm{O}_{2}$-applied group was 1.4 and 2.0-fold higher than the control and DPI groups, respectively. Moreover, the lowest spm concentration was determined in the DPI group (Figure 4).

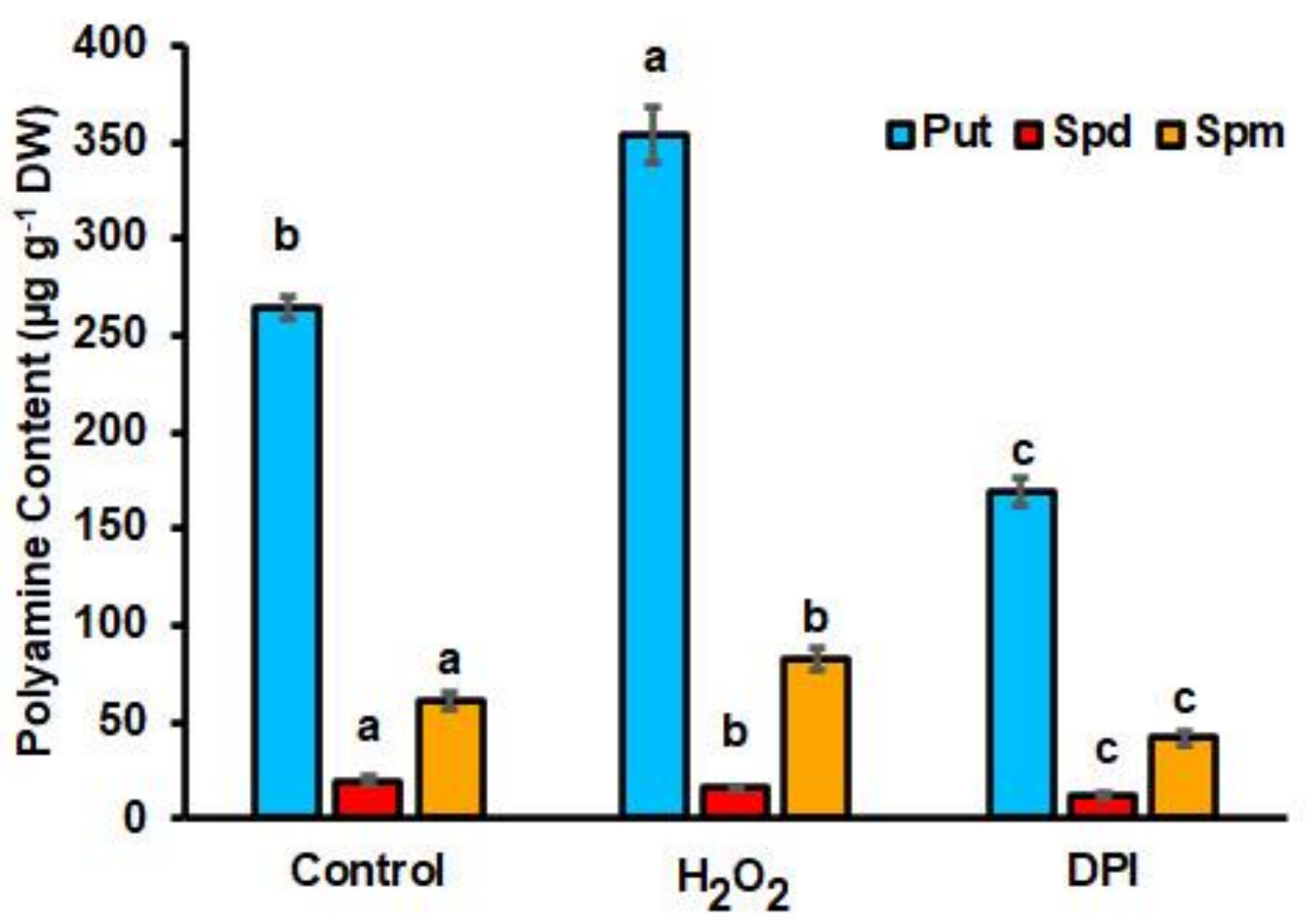

Figure 4- Effect of exogenous $\mathrm{H}_{2} \mathrm{O}_{2}$ and DPI on endogenous polyamine contents in the leaves of detached maize seedlings under PEG-induced drought stress conditions.

Abass \& Mohamed (2011) suggested that the application of $\mathrm{H}_{2} \mathrm{O}_{2}$ to bean seeds stimulated polyamine content under drought conditions. Similarly, Terzi et al. (2014) exposed maize seedlings to osmotic stress after performing pre-treatment of $\mathrm{H}_{2} \mathrm{O}_{2}$ and found significant increases in the put, spm and spd contents. Besides, in our study, the decrease in polyamine level due to DPI application supported the idea that NOX-induced $\mathrm{H}_{2} \mathrm{O}_{2}$ may have a stimulating effect on the polyamine synthesis pathways.

The level of expression of the $A D C$ gene, located in the first stage of the put synthesis, increased with the application of $\mathrm{H}_{2} \mathrm{O}_{2}$ in comparison to the other groups in our study. The $A D C$ expression of the $\mathrm{H}_{2} \mathrm{O}_{2}$-treated group was 1.2 and 1.3 -fold higher than the control and DPI groups, respectively (Figure 5a). The put pool is mainly under the control of the $A D C$ gene and shows an increase in drought stress (Urano et al. 2004; Alcazar et al. 2010b). For this reason, the increase in the putrescine level in the experimental group with $\mathrm{H}_{2} \mathrm{O}_{2}$-applied may be related to the increased expression level of the $A D C$ gene. Indeed, Urano et al. (2004) reported that the increase in putrescine levels in Arabidopsis plants under drought conditions was positively correlated with the stimulation of ADC transcripts. This positive relationship between ADC and putrescine, which we found in our study, was similar to the one obtained by Urano et al. (2004). Abass \& Mohamed (2011) and Terzi et al. (2014), in their drought-related stress studies, determined that the application of $\mathrm{H}_{2} \mathrm{O}_{2}$ increased the polyamine content. Our findings were consistent with the 
data from these researchers. In addition, the RT PCR analyses of the present study confirmed our opinion that $\mathrm{H}_{2} \mathrm{O}_{2}$ promoted the accumulation of polyamines.

In contrast to $\mathrm{H}_{2} \mathrm{O}_{2}$, DPI decreased the expression level of the $A D C$ gene by 1.1-times compared to the control group (Figure 5a). The downregulation of the $A D C$ gene through DPI also supported the idea that $\mathrm{H}_{2} \mathrm{O}_{2}$ derived from NOX may be necessary for the regulation of polyamine biosynthesis. The transcript level of the agmatine aminohydrolase $(A I H)$ gene, which is another enzyme involved in putrescine synthesis, was enhanced with the application of $\mathrm{H}_{2} \mathrm{O}_{2}$ (Figure 5b). The $A I H$ expression of $\mathrm{H}_{2} \mathrm{O}_{2}-$ applied group was 2.2 and 3.3-fold higher than that of the control and the DPI groups, respectively. Because of the DPI application, the $A I H$ expression level was reduced by 1.5 times compared to the control group.

The level of expression of the $A I H$ gene has been reported to increase in Arabidopsis plants exposed to drought stress (Alcazar et al. 2006b). According to the results of our study, another reason for the increase in putrescine due to the application of $\mathrm{H}_{2} \mathrm{O}_{2}$ was the positive regulation of the $A I H$ gene. At the same time, the decrease in the AIH transcript level with DPI application indicated that $\mathrm{H}_{2} \mathrm{O}_{2}$ could regulate the expression level of the gene in question, and the level of putrescine increased. Alcazar et al. (2011) and Do et al. (2014) found elevated levels of transcripts of spermidine synthase (SPDS) genes in Arabidopsis and rice plants, respectively, under drought stress conditions. In our study, the amount of spd was found to be decreasing in the $\mathrm{H}_{2} \mathrm{O}_{2}$ group compared to the control group. This decrease might be caused by the recovery of spermidine into the putrescine pool through PAO activity or by the reduction of transcripts of the SPDS gene because the SPDS gene in the control group was more expressed than the $\mathrm{H}_{2} \mathrm{O}_{2}$ group in our study. The expression level of $S P D S$ in the control group 1.8-fold higher than $\mathrm{H}_{2} \mathrm{O}_{2}$ group (Figure 5d). Furthermore, the low level of expression of $P A O$ in the $\mathrm{H}_{2} \mathrm{O}_{2}$ group compared to the control group may help explain the fluctuations in spermidine levels.
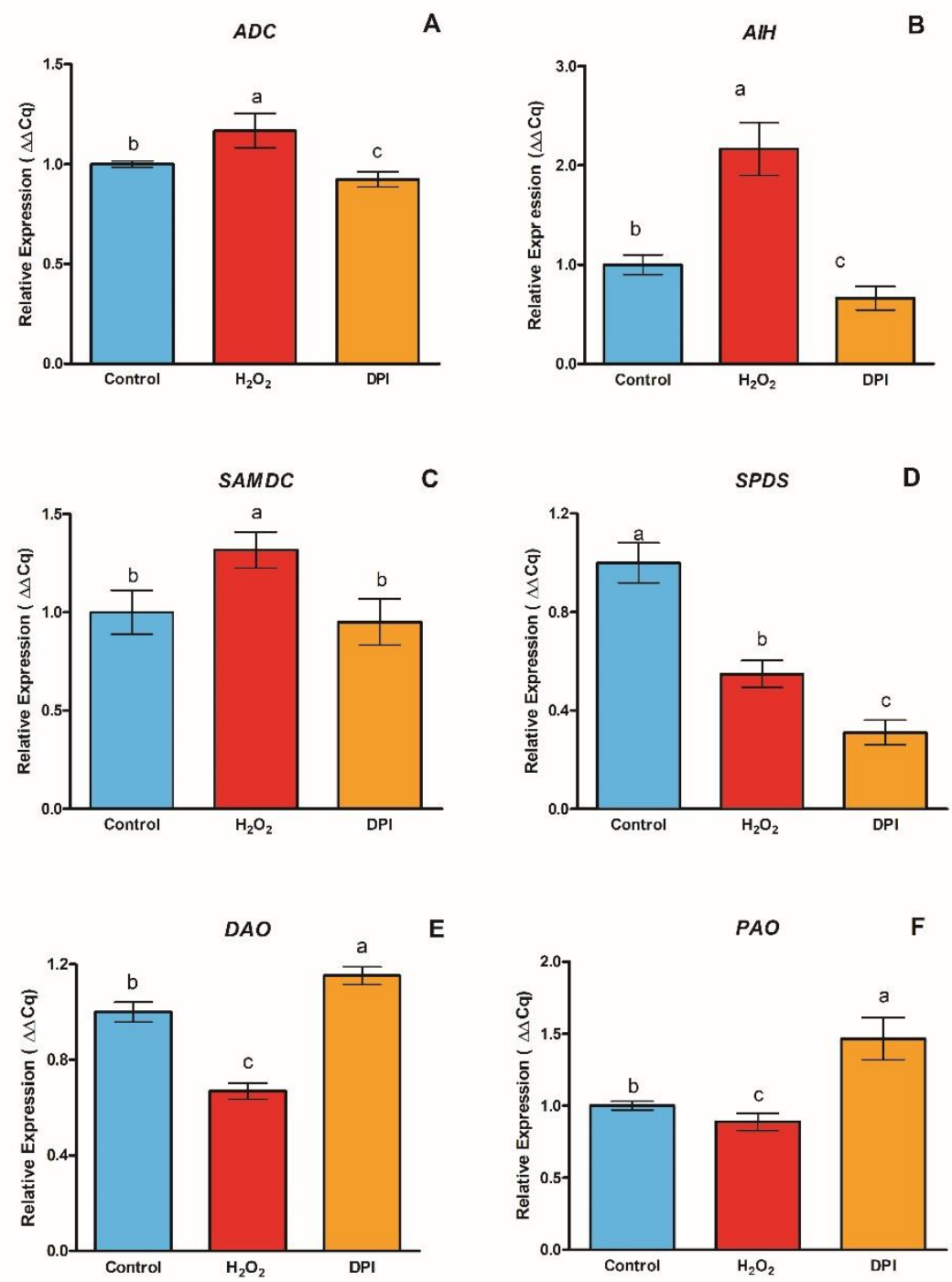

Figure 5- Effect of exogenous $\mathrm{H}_{2} \mathrm{O}_{2}$ and DPI on gene expression levels of Arginine decarboxylase (A), Agmatine iminohydrolase (B), S-adenosylmethionine decarboxylase (C), Spermidine synthase (D), Diamine oxidase (E), Polyamine oxidase (F) in the leaves of detached maize seedlings under PEG-induced drought stress conditions. 
In conclusion, according to the control group, the decrease in endogenous spd level in our study due to the $\mathrm{H}_{2} \mathrm{O}_{2}$ application was consistent with the reduction in the expression level of the SPDS gene. In our study, the expression level of the S-adenosyl methionine decarboxylase $(S A M D C)$ gene, which is involved in the synthesis of spd and spm, was determined. The level of expression of $S A M D C$ was significantly enhanced by $\mathrm{H}_{2} \mathrm{O}_{2}$ treatment. The expression level of $S A M D C$ in the $\mathrm{H}_{2} \mathrm{O}_{2}$-applied group was 1.3 and 1.4-fold higher than the control and the DPI groups, respectively (Figure 5c). The measurement of the degree of expression of this gene provided valuable information for the regulation of spd and spm concentrations. A limited number of studies reported increases in SAMDC expression levels under the stress of drought. For example, under drought stress conditions, there has been an increase in SAMDC transcripts in Arabidopsis and rice plants (Li \& Chen 2000; Alcazar et al. 2011). In addition, the level of spm was reported to increase in rice plants subject to drought stress (Capell et al. 2004). In our study, under drought conditions, the $S A M D C$ transcription level when $\mathrm{H}_{2} \mathrm{O}_{2}$ was applied was higher than other experimental groups. This was consistent with the increased spermine level with hydrogen peroxide application. As in our study, Terzi et al. (2014) reported increases in spm levels as a result of $\mathrm{H}_{2} \mathrm{O}_{2}$ treatment in maize seedlings subjected to osmotic stress. Furthermore, increased expression of a $S A M D C$ by $\mathrm{H}_{2} \mathrm{O}_{2}$ in our study supported the idea that $\mathrm{H}_{2} \mathrm{O}_{2}$ plays an important role in the regulation of polyamine biosynthesis.

Several studies have reported that genes involved in the destruction of polyamines encode diamine oxidase (DAO) and PAO enzymes (Cohen 1998; Angelini et al. 2010; Fincato et al. 2012). In our study, the expression of the DAO gene was significantly decreased by $\mathrm{H}_{2} \mathrm{O}_{2}$ application in drought conditions compared to other groups. The exogenous $\mathrm{H}_{2} \mathrm{O}_{2}$ treatment reduced the expression level of the $D A O$ gene as 1.5 -fold than the control group (Figure 5e). This reduction may help explain the high level of put in the $\mathrm{H}_{2} \mathrm{O}_{2}$ group compared with other groups. DPI application was the group with the highest level of $D A O$ transcript. The gene expression level of $D A O$ in the DPI group was 1.2 and 1.7-fold higher than the control and the $\mathrm{H}_{2} \mathrm{O}_{2}$-treated groups, respectively (Figure 5e). This was confirmed by examining putrescine rates. Regulation of the DAO gene supported the idea that there could be a crosstalk between $\mathrm{H}_{2} \mathrm{O}_{2}$ and polyamine levels during drought stress. In our study, the levels of $P A O$ transcripts in the control and DPI groups were higher than the $\mathrm{H}_{2} \mathrm{O}_{2}$ group under drought conditions. The level of expression of the $P A O$ gene in the DPI group was 1.5 and 1.7 times higher than that of the control and $\mathrm{H}_{2} \mathrm{O}_{2}$ groups, respectively. On the other hand, the expression level measured in the $\mathrm{H}_{2} \mathrm{O}_{2}$ group was 1.1-fold lower than the control group (Figure 5f).

Alcazar et al. (2011) reported a rise in $P A O$ expression in drought-exposed Arabidopsis plants. In another study, $P A O$ transcripts were also found to increase significantly, while put and spd levels decreased in grape varieties exposed to drought stress (Hatmi et al. 2015).

On the other hand, the application of $\mathrm{H}_{2} \mathrm{O}_{2}$ which we carried out in our study resulted in a decrease in $P A O$ transcripts and an increase in polyamine levels. This was evidenced by the rise in the putrescine rate in the $\mathrm{H}_{2} \mathrm{O}_{2}$ group. The increased expression level of the $P A O$ gene by DPI also supported that NOX-derived $\mathrm{H}_{2} \mathrm{O}_{2}$ had a regulatory role in polyamine degradation.

Superoxide $\left(\mathrm{O}_{2} \cdot{ }^{-}\right)$and $\mathrm{H}_{2} \mathrm{O}_{2}$, the most studied ROS derivatives, have critical roles in many processes (Pitzschke et al. 2006; Dikalov et al. 2011; Suzuki et al. 2013). In our study, DPI reduced the $\mathrm{H}_{2} \mathrm{O}_{2}$ accumulation by blocking the NADPH oxidase enzyme, which resulted in significant reductions in polyamine levels. Furthermore, the levels of expression of $D A O$ and $P A O$ responsible for polyamine degradation increased. On the other hand, the model of polyamine oxidation initiated by the $\mathrm{H}_{2} \mathrm{O}_{2}$ signal cascade has been accepted because $\mathrm{H}_{2} \mathrm{O}_{2}$ is a direct product of polyamine oxidation (Moschou et al. 2008b). In summary, the literature indicates that polyamine metabolism can be regulated by $\mathrm{H}_{2} \mathrm{O}_{2}$, which is derived from the activities of DAO and PAO enzymes. However exogenously applied $\mathrm{H}_{2} \mathrm{O}_{2}$ in our study decreased the gene expression level of the $D A O$ and $P A O$, while leading to an increase in expressions of $A D C, A I H, S P D S$, and $S A M D C$. So, according to our study, it concluded that $\mathrm{H}_{2} \mathrm{O}_{2}$ was capable of positive regulation on polyamine metabolism. Consequently, in our study, not only $\mathrm{H}_{2} \mathrm{O}_{2}$ due to polyamine oxidation, but also $\mathrm{H}_{2} \mathrm{O}_{2}$ derived from NADPH oxidase and externally applied $\mathrm{H}_{2} \mathrm{O}_{2}$ affects polyamine signaling. Because when $\mathrm{NOX}$ is inhibited, the metabolic pathway has shifted from synthesis to breakdown.

\section{Conclusions}

Based on the data obtained in this study, a model diagram showing the potential $\mathrm{H}_{2} \mathrm{O}_{2}$-polyamine relationship was established (Figure 6). The model of polyamine metabolism controlled by hydrogen peroxide can be summarized as follows. $\mathrm{H}_{2} \mathrm{O}_{2}$ which was applied externally in drought conditions, probably induced both $\mathrm{NOX}$ gene expression and enzyme activity. Then, $\mathrm{H}_{2} \mathrm{O}_{2}$ induced the expression of $A D C, A I H, S P D S$, and $S A M D C$, one of the polyamine synthesis genes, directly or indirectly, by other possible metabolic pathways. Due to the increased level of gene expression, the amount of endogenous polyamine has increased. Besides, $\mathrm{H}_{2} \mathrm{O}_{2}$ has been suggested to reduce the production of polyamine oxidation enzymes by directly or indirectly suppressing the expression of polyamine degradation genes. In conclusion, $\mathrm{H}_{2} \mathrm{O}_{2}$ plays an essential regulation role in the metabolism of polyamines by adjusting the expressions of genes for the synthesis and degradation of polyamines. 


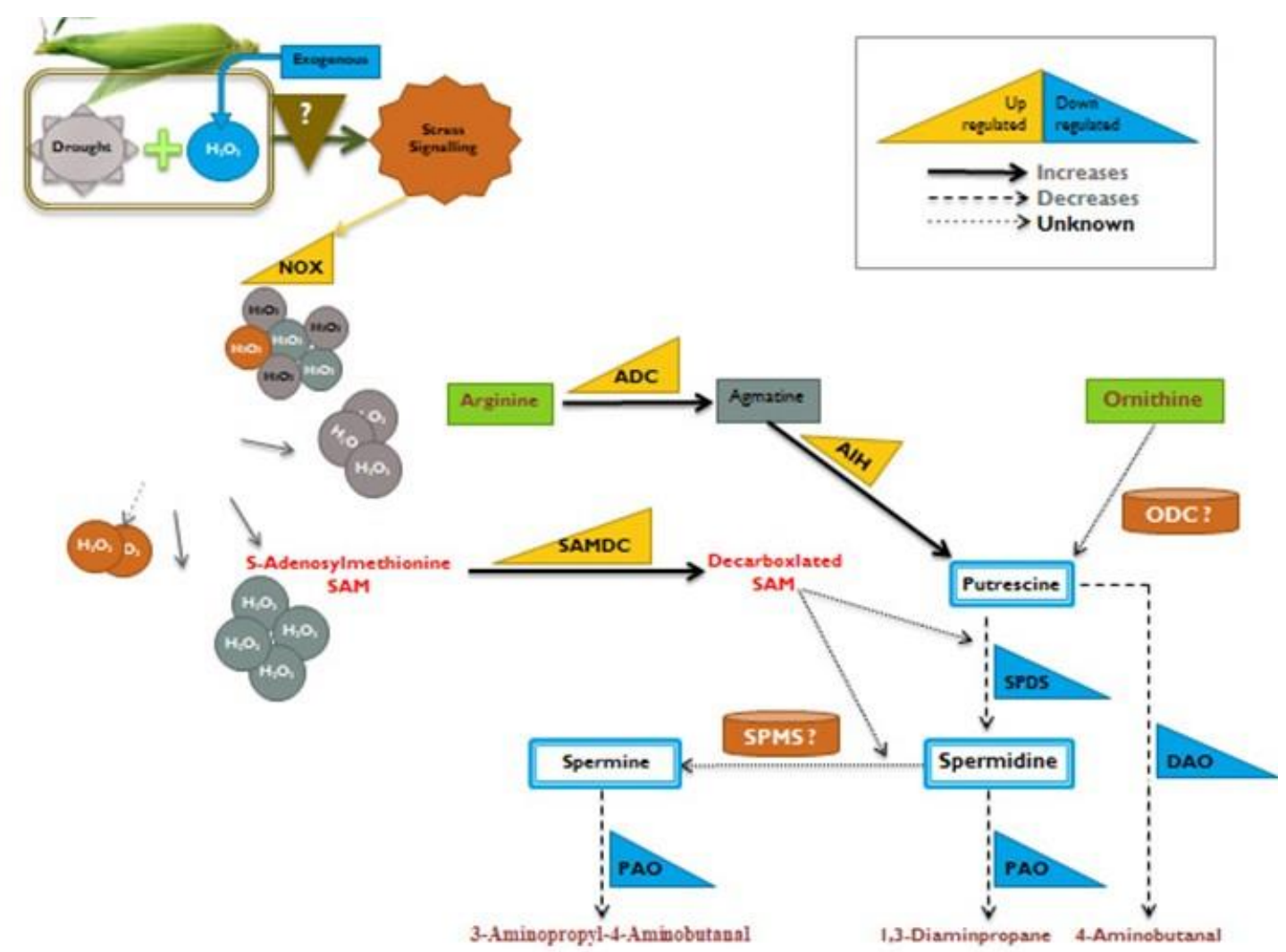

Figure 6- Putative $\mathrm{H}_{2} \mathrm{O}_{2}$-related polyamine metabolism under drought stress conditions

\section{Acknowledgements}

This study was supported by The Scientific and Technological Research Council of Turkey through the project $113 Z 863$. Authors thanks to Prof. Dr. Ahmet YASAR for helping measurements of polyamine contents

\section{References}

Abass M S \& Mohamed H I (2011). Alleviation of adverse effects of drought stress on common bean (Phaseolus vulgaris L.) by exogenous application of hydrogen peroxide. Bangladesh Journal of Botany 40: 75-83. doi: 10.3329/bjb.v40i1.8001

Aebi H E (1983). Catalase. In: Bergmeyer H U (Ed.), Methods of Enzymatic Analysis, Verlag Chemie, Germany pp. 273-286

Akyol T Y, Yılmaz O, Uzilday B, Özgür Uzilday R \& Türkan I (2020). Plant response to salinity: an analysis of ROS formation, signaling, and antioxidant defense. Turkish Journal of Botany 44: 1-13. doi:10.3906/bot-1911-15

Alcazar R, Cuevas J C, Patron M, Altabella T \& Tiburcio A F (2006a). Abscisic acid modulates polyamine metabolism under water stress in Arabidopsis thaliana. Physiologia Plantarum 128: 448-455. doi: 10.1111/j.1399-3054.2006.00780.x

Alcazar R, Marco F, Cuevas J C, Patron M, Ferrando A, Carrasco P, Tiburcio A F \& Altabella T (2006b). Involvement of polyamines in plant response to abiotic stress. Biotechnology Letters 28: 1867-1876. doi: 10.1007/s10529-006-9179-3

Alcazar R, Planas J, Saxena T, Zarza X, Bortolotti C, Cuevas J, Bitrian M, Tiburcio A F \& Altabella T (2010a). Putrescine accumulation confers drought tolerance in transgenic Arabidopsis plants overexpressing the homologous Arginine decarboxylase 2 gene. Plant Physiology and Biochemistry 48: 547-552. doi: 10.1007/s00425-010-1130-0

Alcazar R, Altabella T, Marco F, Bortolitto C, Reymond M, Koncz C, Carasso P \& Tiburcio A F (2010b). Polyamines: Molecules with regulatory functions in plant abiotic stress tolerance. Planta 231: 1237-1249. doi: 10.1016/j.plaphy.2010.02.002

Alcazar R, Bitrian M, Bartels D, Koncz C, Altabella T \& Tiburcio A F (2011). Polyamine metabolic canalization in response to drought stress in Arabidopsis and the resurrection plant Craterostigma plantagineum. Plant Signaling and Behavior 6: 243-250. doi: 10.4161/psb.6.2.14317

Andronis A E, Moschou P N, Toumi I \& Roubelakis-Angelakis K A (2014). Peroxisomal polyamine oxidase and NADPH-oxidase cross-talk for ROS homeostasis which affects respiration rate in Arabidopsis thaliana. Frontiers in Plant Science 5: 132. doi: 10.3389/fpls.2014.00132

Angelini R, Cona A, Federico R, Fincato P, Tavladoraki P \& Tisi A (2010). Plant amine oxidases “on the move": an update. Plant Physiology and Biochemistry 48: 560-564 doi: 10.1016/j.plaphy.2010.02.001

Bailey-Serres J \& Mittler R (2006). The roles of reactive oxygen species in plant cells. Plant Physiology 141: 311. doi: 10.1104/pp.104.900191

Beauchamp C \& Fridovich I (1971). Superoxide dismutase: improved assays and an assay applicable to acrylamide gels. Analytical Biochemistry 44: 276-287. doi: 10.1016/0003-2697(71)90370-8

Bradford M M (1976). Rapid and sensitive method for the quantitation of microgram quantities of protein utilizing the principle of protein-dye binding. Analytical Biochemistry 72: 248-254. doi: 10.1006/abio.1976.9999

Cakmak I \& Marschner H (1988). Zinc-dependent changes in ESR signals, NADPH oxidase and plasma membrane permeability in cotton roots. Physiologia Plantarum 73: 182-186. doi: 10.1111/j.1399-3054.1988.tb09214.x 
Capell T, Bassie L \& Christou P (2004). Modulation of the polyamine biosynthetic pathway in transgenic rice confers tolerance to drought stress. Proceedings of the National Academy of Sciences of the United States of America 101: 9909-9914. doi: 10.1073/pnas.0306974101

Chaudiere J \& Ferrari-Iliou R (1999). Intracellular antioxidants from chemical to biochemical mechanisms. Food and Chemical Toxicology 37: 949-962. doi: 10.1016/s0278-6915(99)00090-3

Cohen S S (1998). A Guide to The Polyamines. Oxford University Press, New York

Cona A, Rea G, Angelini R, Federico R \& Tavladoraki P (2006a). Functions of amine oxidases in plant development and defence. Trends in Plant Science 11: 80-88. doi: 10.1016/j.tplants.2005.12.009

Cona A, Rea G, Botta M, Corelli F, Federico R \& Angelini R (2006b). Flavin-containing polyamine oxidase is a hydrogen peroxide source in the oxidative response to the protein phosphatase inhibitor cantharidin in Zea mays. Journal of Experimental Botany 57: 2277-2289. doi: $10.1093 / \mathrm{jxb} / \mathrm{erj} 195$

Cruz de Carvalho MH (2008). Drought stress and reactive oxygen species. Plant Signaling and Behavior 3: 156-165. doi: 10.4161/psb.3.3.5536

Das K \& Roychoudhury A (2014). Reactive oxygen species (ROS) and response of antioxidants as ROS-scavengers during environmental stress in plants. Frontiers in Environmental Science 2: 53. doi: 10.3389/fenvs.2014.00053

Do P T, Drechsel O, Heyer A G, Hincha D K \& Zuther E (2014). Changes in free polyamine levels, expression of polyamine biosynthesis genes and performance of rice cultivars under salt stress: A comparison with responses to drought. Frontiers in Plant Science 5: 182. doi: $10.3389 /$ fpls.2014.00182

Dikalov S, Nazarewicz R, Panov A, Harrison D G \& Dikalova A (2011). Crosstalk between mitochondrial ROS and NADPH oxidases in cardiovascular and degenerative diseases: Application of mitochondria-targeted antioxidants. Free Radical Biology and Medicine 51: 8586. doi: 10.1016/j.freeradbiomed.2011.06.033

Erdei L, Szegletes Z, Barabas K \& Pestenacz A (1996). Responses in polyamine under osmotic and salt stress in sorghum and maize seedlings. Journal of Plant Physiology 147: 599-603. doi: 10.1016/S0176-1617(96)80052-6

Fincato P, Moschou P N, Spedaletti V, Tavazza R, Angelini R, Federico R, Roubelakis-Angelakis K A \& Tavladoraki P (2011). Functional diversity inside the Arabidopsis polyamine oxidase gene family. Journal of Experimental Botany 62: 1155-1168. doi: 10.1093/jxb/erq341

Fincato P, Moschou P N, Ahou A, Angelini R, Roubelakis-Angelakis K A, Federico R \& Tavladoraki P (2012). The members of Arabidopsis thaliana $P A O$ gene family exhibit distinct tissue and organ-specific expression pattern during seedling growth and flower development. Amino Acids 42: 831-841. doi: 10.1007/s00726-011-0999-7

Galston A W, Kaur-Sawhney R, Altabella T \& Tiburcio A F (1997). Plant polyamines in reproductive activity and response to abiotic stress. Botanica Acta 110: 197-207. doi: 10.1111/j.1438-8677.1997.tb00629.x

Gill S \& Tuteja N (2010). Polyamines and abiotic stress tolerance in plants. Plant Signaling \& Behavior 5: 26-33. doi: 10.4161/psb.5.1.10291

Groppa M D \& Benavides M P (2008). Polyamines and abiotic stress: Recent advances. Amino Acids 34: 35-45. doi: 10.1007/s00726-0070501-8

Guven F G (2013). Effect of alpha lipoic acid pre-treatment on drought tolerance in drought-sensitive and drought-resistant maize genotypes. Master thesis, Karadeniz Technical University, Turkey

Hatmi S, Gruau C, Trotel-Aziz P, Villaume S, Rabenoelina F, Baillieul F, Eullaffroy P, Clément C, Ferchichi A \& Aziz A (2015). Drought stress tolerance in grapevine involves activation of polyamine oxidation contributing to improved immune response and low susceptibility to Botrytis cinerea. Journal of Experimental Botany 66: 775-787. doi: 10.1093/jxb/eru436

$\mathrm{He}$ L, Gao Z \& Li R (2009). Pretreatment of seed with $\mathrm{H}_{2} \mathrm{O}_{2}$ enhances drought tolerance of wheat (Triticum aestivum L.) seedlings. African Journal of Biotechnology 8: 6151-6157. doi: 10.5897/AJB09.490

Heath R L \& Packer L (1968). Photoperoxidation in isolated chloroplasts. I. kinetics and stoichiometry of fatty acid peroxidation. Archives of Biochemistry and Biophysics 125: 189-198. doi: 10.1016/0003-9861(68)90654-1

Kusano T, Yamaguchi K, Berberich T \& Takahashi Y (2007). The polyamine spermine rescues Arabidopsis from salinity and drought stresses. Plant Signaling and Behavior 2: 251-252. doi: 10.4161/psb.2.4.3866

Kusano T, Berberich T, Tateda C \& Takahashi Y (2008). Polyamines: Essential factors for growth and survival. Planta 228: 367-381. doi: $10.1007 / \mathrm{s} 00425-008-0772-7$

Kwak J M, Mori I C, Pei Z M, Leonhardt N, Torres M A, Dangl J L, Bloom R E, Bodde S, Jones J D G \& Schroeder J I (2003). NADPH oxidase AtrbohD and AtrbohF genes function in ROS-dependent ABA signaling in Arabidopsis. EMBO Journal 22: 2623-2633. doi: 10.1093/emboj/cdg277

Li Z Y \& Chen S Y (2000). Differential accumulation of the S-adenosylmethionine decarboxylase transcript in rice seedlings in response to salt and drought stresses. Theoretical and Applied Genetics 100: 782-788. doi: 10.1007/s001220051

Liu Z J, Guo Y K \& Bai J G (2010). Exogenous hydrogen peroxide changes antioxidant enzyme activity and protects ultrastructure in leaves of two cucumber ecotypes under osmotic stress. Journal of Plant Growth Regulation 29: 171-183. doi: 10.1007/s00344-009-9121-8

Liu C, Atanasov K E, Tiburcio A F \& Alcázar R (2019). The polyamine putrescine contributes to $\mathrm{H}_{2} \mathrm{O}_{2}$ and $R b o h D / F$-dependent positive feedback loop in Arabidopsis PAMP-Triggered Immunity. Frontiers in Plant Science 10: 894. https://doi.org/10.3389/fpls.2019.00894

Moschou P N, Delis I D, Paschalidis K A \& Roubelakis-Angelakis K A (2008a). Transgenic tobacco plants overexpressing polyamine oxidase are not able to cope with oxidative burst generated by abiotic factors. Physiologia Plantarum 133: 140-156. doi: 10.1111/j.13993054.2008.01049.x

Moschou P N, Paschalidis K A \& Roubelakis-Angelakis K A (2008b). Plant polyamine catabolism: The state of the art. Plant Signaling and Behavior 3: 1061-1066. doi: 10.4161/psb.3.12.7172

Munne-Bosch S, Jubany-Mari T \& Alegre L (2001). Drought-induced senescence is characterized by a loss of antioxidant defences in chloroplasts. Plant Cell and Environment 24: 1319-1327. doi: 10.1046/j.1365-3040.2001.00794.x

Papadakis A K \& Roubelakis-Angelakis K A (2005). Polyamines inhibit NADPH oxidase-Mediated superoxide generation and putrescine prevents programmed cell death induced by polyamine oxidase-generated hydrogen peroxide. Planta 220: 826-837. doi: 10.1007/s00425004-1400-9

Parida A K \& Das A B (2005). Salt tolerance and salinity effects on plants: a review. Ecotoxicology and Environmental Safety 60: 324-349. doi: 10.1016/j.ecoenv.2004.06.010

Pitzschke A, Forzani C \& Hirt H (2006). Reactive oxygen species signaling in plants. Antioxidants and Redox Signaling 8: 1757-1764. doi: 10.1089/ars.2006.8.1757

Potocký M, Jones M A, Bezvoda R, Smirnoff N \& Žárský V (2007). Reactive oxygen species produced by NADPH oxidase are involved in pollen tube growth. New Phytologist 174: 742-51. doi: 10.1111/j.1469-8137.2007.02042.x 
Rodríguez-Rojas A, Kim J J, Johnston P R, Makarova O, Eravci M, Weise C, Hengge R \& Rolff J (2020). Non-lethal exposure to $\mathrm{H}_{2} \mathrm{O}_{2}$ boosts bacterial survival and evolvability against oxidative stress. PLoS Genetics 16(3): e1008649. doi: 10.1371/journal.pgen.1008649

Sagi M, Davydov O, Orazova S, Yesbergenova Z, Ophir R, Stratmann J W \& Fluhr R (2004). Plant respiratory burst oxidase homologs impinge on wound responsiveness and development in Lycopersicon esculentum. Plant Cell 16: 616-628. doi: 10.1105/tpc.019398

Saglam A, Saruhan N, Terzi R \& Kadioğlu A (2011). The relations between antioxidant enzymes and chlorophyll fluorescence parameters in common bean cultivars differing in sensitivity to drought stress. Russian Journal of Plant Physiology 58: 60-68. doi:10.1134/S102144371101016X

Seo S Y, Kim Y J \& Park K Y (2019). Increasing polyamine contents enhances the stress tolerance via reinforcement of antioxidative properties. Frontiers in Plant Science 10: 1331. doi: 10.3389/fpls.2019.01331

Sequera-Mutiozabal M, Antoniou C, Tiburcio A F, Alcázar R \& Fotopoulos V (2017). Polyamines: Emerging hubs promoting drought and salt stress tolerance in plants. Current Molecular Biology Reports 3: 28-36. doi: 10.1007/s40610-017-0052-z

Sharma P \& Dubey R S (2005). Drought induces oxidative stress and enhances the activities of antioxidant enzymes in growing rice seedlings. Plant Growth Regulation 46: 209-221. doi: 10.1007/s10725-005-0002-2

Shaw B, Thomas T H \& Cooke D T (2002). Responses of sugar beet (Beta vulgaris) to drought and nutrient deficiency stress. Plant Growth Regulation 37: 77-83. doi: 10.1023/A:1020381513976

Siddique M R B, Hamid A \& Islam M S (2000). Drought stress effects on water relations of wheat. Botanical Bulletin of Academia Sinica 41: 35-39

Suzuki N, Miller G, Salazar C, Mondal H A, Shulaev E, Cortes D F, Shuman J L, Luo X, Shah J, Schlauch K, Shulaev V \& Mittler R (2013). Temporal-spatial interaction between reactive oxygen species and Abscisic acid regulates rapid systemic acclimation in plants. Plant Cell 25: 3553-3569. doi: 10.1105/tpc.113.114595

Terzi R, Kadioglu A, Kalaycioglu E \& Saglam A (2014). Hydrogen peroxide pretreatment induces osmotic stress tolerance by influencing osmolyte and abscisic acid levels in maize leaves. Journal of Plant Interactions 9: 559-565. doi: 10.1080/17429145.2013.871077

Torres M A, Jones J D G \& Dangl J L (2005). Pathogen-induced, NADPH oxidase-derived reactive oxygen intermediates suppress spread of cell death in Arabidopsis thaliana. Nature Genetics 37: 1130-1134. doi: 10.1038/ng1639

Urano K, Yoshiba Y, Nanjo T, Ito T, Yamaguchi-Shinozaki K \& Shinozaki K (2004). Arabidopsis stress-inducible gene for Arginine decarboxylase AtADC2 is required for accumulation of putrescine in salt tolerance. Biochemical and Biophysical Research Communications 313: 369-375. doi: 10.1016/j.bbrc.2003.11.119

Urbanek H, Kuzniak-Gebarowska E \& Herka K (1991). Elicitation of defense responses in bean leaves by Botrytis cinerea polygalacturanase, Acta Physiologiae Plantarum 13: 43-50

Velikova V, Yordanov I \& Edreva A (2000). Oxidative stress and some antioxidant systems in acid rain-treated bean plants: Protective roles of exogenous polyamines. Plant Science 151: 59-66. doi: 10.1016/S0168-9452(99)00197-1

Waszczak C, Carmody M \& Kangasjärvi J (2018). Reactive oxygen species in plant signaling. Annual Review of Plant Biology 29: 209-236. doi: 10.1146/annurev-arplant-042817-040322

Wu J, Shang Z, Jiang X, Moschou P N, Sun W, Roubelakis-Angelakis K A \& Zhang S (2010). Spermidine oxidase-derived $\mathrm{H}_{2} \mathrm{O}_{2}$ regulates pollen plasma membrane hyperpolarization-activated $\mathrm{Ca}^{+2}$-permeable channels and pollen tube growth. Plant Journal 63: 1042-1053. doi: $10.1111 / \mathrm{j} .1365-313 X .2010 .04301 . \mathrm{x}$

Yamaguchi K, Takahashi Y, Berberich T, Imai A, Miyazaki A, Takahashi T, Michael A \& Kusano T (2006). The polyamine spermine protects against high salt stress in Arabidopsis thaliana. FEBS Letters 580: 6783-6788. doi: 10.1016/j.febslet.2006.10.078

Yamaguchi K, Takahashi Y, Berberich T, Imai A, Takahashi, T, Michael, A J \& Kusano T (2007). A protective role for the polyamine spermine against drought stress in Arabidopsis. Biochemical and Biophysical Research Communications 352: 486-490. doi: 10.1016/j.bbrc.2006.11.041

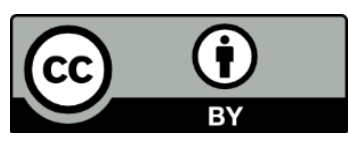

(C) 2022 by the author(s). Published by Ankara University, Faculty of Agriculture, Ankara, Turkey. This is an Open Access article distributed under the terms and conditions of the Creative Commons Attribution (CC BY) license (http://creativecommons.org/licenses/by/4.0/), which permits unrestricted use, distribution, and reproduction in any medium, provided the original work is properly cited. 